Research Paper

\title{
Hexavalent chromium reduction by aerobic heterotrophic bacteria indigenous to chromite mine overburden
}

\author{
Satarupa Dey, A.K. Paul \\ Microbiology Laboratory, Department of Botany, University of Calcutta, Kolkata, India.
}

Submitted: November 8, 2011; Approved: July 2, 2012.

\begin{abstract}
Microbiological analysis of overburden samples collected from chromite mining areas of Orissa, India revealed that they are rich in microbial density as well as diversity and dominated by Gramnegative (58\%) bacteria. The phenotypically distinguishable bacterial isolates (130) showed wide degree of tolerance to chromium $(2-8 \mathrm{mM})$ when tested in peptone yeast extract glucose agar medium. Isolates (92) tolerating $2 \mathrm{mM}$ chromium exhibited different degrees of $\mathrm{Cr}^{+6}$ reducing activity in chemically defined Vogel Bonner (VB) broth and complex KSC medium. Three potent isolates, two belonging to Arthrobacter spp. and one to Pseudomonas sp. were able to reduce more than 50 and $80 \%$ of $2 \mathrm{mM}$ chromium in defined and complex media respectively. Along with $\mathrm{Cr}^{+6}$ (MIC 8.6-17.8 mM), the isolates showed tolerance to $\mathrm{Ni}^{+2}, \mathrm{Fe}^{+3}, \mathrm{Cu}^{+2}$ and $\mathrm{Co}^{+2}$ but were extremely sensitive to $\mathrm{Hg}^{+2}$ followed by $\mathrm{Cd}^{+2}, \mathrm{Mn}^{+2}$ and $\mathrm{Zn}^{+2}$. In addition, they were resistant to antibiotics like penicillin, methicillin, ampicillin, neomycin and polymyxin B. During growth under shake-flask conditions, Arthrobacter SUK 1201 and SUK 1205 showed 100\% reduction of $2 \mathrm{mM} \mathrm{Cr}^{+6}$ in KSC medium with simultaneous formation of insoluble precipitates of chromium salts. Both the isolates were also equally capable of completely reducing the $\mathrm{Cr}^{+6}$ present in mine seepage when grown in mine seepage supplemented with VB concentrate.
\end{abstract}

Key words: chromite overburden, hexavalent chromium, chromate reduction, Arthrobacter, Pseudomonas.

\section{Introduction}

Chromium, the transition metal with its most stable hexavalent $\left[\mathrm{Cr}^{+6}\right]$ and trivalent $\left[\mathrm{Cr}^{+3}\right]$ forms are widely distributed in the environment as a result of diverse anthropogenic activities (Megharaj et al., 2003; Mishra et al., 2010) as well as geogenous occurrence (Pal et al., 2005). Mining operations, both open cast and underground, in chromite ore deposits often generate huge overburdens in and around the mining areas. These overburden materials are solid waste piles containing rejected minerals, waste rocks, very poor or low grade chromite ores and soils. Natural leaching and weathering of these waste overburden materials often lead to the generation and percolation of hexavalent chromium, which is of serious concern for environmental contamination and pollution (Dhal et al., 2010).
In India, the state of Orissa represents about $97 \%$ of the countries chromite deposits, which are localized mainly in Sukinda Valley and Baula-Nuasahi belt of Jajpur and Keonjhar districts respectively. Over the years, mining activities both by the government and private agencies have led to the deposition of about 7.6 tonnes of overburden (Tiwary et al., 2005). This has not only disrupted the ecological balance of the area but has also became the main source of hexavalent chromium contamination (Godgul and Sahu, 1995; Samantaroy et al., 1999). Health hazards of mine workers as well as inhabitants of the surrounding areas have attracted the attention of researchers and environment protection agencies and emphasized detoxification of $\mathrm{Cr}^{+6}$. Hexavalent chromium mediated toxicity in most living forms is primarily due to its easy uptake across the membrane, development of oxidative stress, DNA dam-

Send correspondence to A.K. Paul. Microbiology Laboratory, Department of Botany, University of Calcutta, 35 Ballygunge Circular Road, 700019 Kolkata, India. E. mail: amalk_paul@yahoo.co.in. 
age, carcinogenicity, mutagenicity and altered gene expression (Bagchi et al., 2002).

Since 1970s, microbial detoxification of $\mathrm{Cr}^{+6}$ has been identified as the eco-friendly and superior alternative over those of conventional physico-chemical strategies (Komori et al., 1990; Camargo et al., 2003), which often generate huge amount of secondary sludge (Thaker and Madamwar, 2005). A large number of organisms capable of reducing $\mathrm{Cr}^{+6}$ under aerobic (Ganguli and Tripathi, 2002; Pal and Paul, 2004; Thaker et al., 2006; Wani et al., 2007) as well as anaerobic (Opperman and Heerden, 2007) conditions have been reported from both anthropogenic (Basu et al., 1997; Viti et al., 2003; Thaker and Madamwar, 2005) as well as geogenous (Pal and Paul, 2004) sources and have the potentials for the development of in situ or ex situ $\mathrm{Cr}^{+6}$ bioremediation strategies.

The present study attempts to isolate chromate resistant and reducing bacteria from chromite mine overburden and evaluate their chromate reducing potentials. Heavy metal and antibiotic resistance along with reduction of $\mathrm{Cr}^{+6}$ in mine seepage by selected bacterial isolates have also been reported.

\section{Materials and Methods}

\section{Collection of samples}

Twelve mine overburden samples collected from open cast as well as under ground chromite mines in and around Sukinda valley and Baula-Nuasahi areas of Orissa, India were used during the present study. The samples were collected from subsurface zones in sterile containers and stored at $4{ }^{\circ} \mathrm{C}$ until used for microbiological analysis.

\section{Microbial analysis}

Population density of aerobic, heterotrophic bacteria in overburden samples was estimated by dilution and plating on peptone yeast extract glucose (PYEG) agar medium (Wang and Xiao, 1995). The medium contained (grams per liter): peptone, 10.0; yeast extract, 5.0 and glucose, $3.0(\mathrm{pH}$ 7.0). The plates were incubated at $28-32{ }^{\circ} \mathrm{C}$ for $2-4$ days and the population density was determined by the number of colony forming units/g of the overburden sample. Phenotypically distinguishable bacterial colonies were further purified and maintained on slopes of PYEG agar at $4{ }^{\circ} \mathrm{C}$.

Hydrolysis of fluorescein diacetate (FDA) (Schnurer and Rosswall, 1982) was used to determine the microbial activity of overburden samples. One gram of freshly collected overburden sample, $24 \mathrm{~mL}$ phosphate buffer $(0.2 \mathrm{~N}, \mathrm{pH} 7.0)$ and $1 \mathrm{~mL}$ of FDA (final concentration $10 \mu \mathrm{g} / \mathrm{mL}$ ) was agitated on a rotary shaker (120 rpm) for $3 \mathrm{~h}$ at $35^{\circ} \mathrm{C}$. The reaction was stopped by adding equal amount of analytical grade acetone, filtered through WHATMAN No. 1 filter paper and optical density measured at $490 \mathrm{~nm}$. The amount of fluorescein released was determined from the calibration curve prepared in the same way. FDA hy- drolyzing activity was expressed as $\mu \mathrm{g}$ fluorescein $/ \mathrm{h} / \mathrm{g}$ of oven dried sample.

\section{Screening for chromate tolerance and reduction}

Bacterial tolerance to chromate was tested by agar dilution method (Cervantes and Ohtake, 1988). PYEG agar supplemented with different concentration of $(2-8 \mathrm{mM})$ hexavalent chromium (as chromate) was inoculated with overnight grown cultures, incubated at $35^{\circ} \mathrm{C}$ for 3-4 days and tolerance to $\mathrm{Cr}^{+6}$ was determined by visual growth.

Reduction of hexavalent chromium by bacterial isolates was determined during growth in Vogel Bonner (VB) broth and modified KSC medium. Vogel Bonner broth was made up of $2.0 \%$ sterile stock solution of VB concentrate. The VB concentrate contained (grams per liter): $\mathrm{K}_{2} \mathrm{HPO}_{4}, 500.0 ; \mathrm{Na}\left(\mathrm{NH}_{4}\right) \mathrm{HPO}_{4} .4 \mathrm{H}_{2} \mathrm{O}, 175.0$; citric acid, $100.0 ; \mathrm{MgSO}_{4} .7 \mathrm{H}_{2} \mathrm{O}, 10.0$ and $2.0 \%$ of $25 \%$ D-glucose $20.0 \mathrm{~mL}$ (pH 7.0) (38). Modified KSC medium contained (grams per liter): $\mathrm{NH}_{4} \mathrm{Cl}, 0.03 ; \mathrm{K}_{2} \mathrm{HPO}_{4}, 0.03$; $\mathrm{KH}_{2} \mathrm{PO}_{4}, 0.05 ; \mathrm{NaCl}, \quad 0.01 ;$ sodium acetate, 2.0; $\mathrm{MgSO}_{4} .7 \mathrm{H}_{2} \mathrm{O}, 0.01 ; \mathrm{CaCO}_{3}, 0.005 ; \mathrm{FeCl}_{3} .7 \mathrm{H}_{2} \mathrm{O}, 0.005$; and glucose 10.0, (pH 7.2) (37). Media $(20 \mathrm{~mL} / 100 \mathrm{~mL}$ flask) supplemented with $2 \mathrm{mM} \mathrm{Cr}^{+6}$ was inoculated with overnight grown culture and incubated at $35^{\circ} \mathrm{C}$ under continuous shaking (120 rpm). Reduction of chromium was estimated by measuring the decrease in hexavalent chromium content of culture filtrate following 1, 5-diphenyl carbazide method (Park et al., 2000).

\section{Bacterial tolerance to heavy metals}

Bacterial tolerance to heavy metals was evaluated following broth dilution method of Calomiris et al. (1984). The VB broth (5 mL/tube) supplemented with increasing concentration of heavy metals was inoculated with $0.2 \mathrm{~mL}$ overnight grown cultures and incubated at $35{ }^{\circ} \mathrm{C}$ for $24-48 \mathrm{~h}$ under continuous shaking (120 rpm). Medium without metal served as control. The lowest concentration of metal ions that inhibited the growth of organism was taken as the minimum inhibitory concentration (MIC) of that metal.

\section{Antibiotic susceptibility}

Susceptibility of selected isolates to different antibiotics was evaluated by disc-diffusion method. Antibiotic impregnated discs (6 mm, dia. HIMEDIA) were placed on freshly prepared lawns of each bacterial isolates on PYEG agar medium and incubated at $35^{\circ} \mathrm{C}$ for $24 \mathrm{~h}$. The diameter of inhibition zone was measured to nearest $\mathrm{mm}$ and isolates were identified as sensitive, resistant and intermediate following standard antibiotic sensitivity testing method (Difco Laboratories, 1984). Discs containing the following antibiotics were used: streptomycin $(25 \mu \mathrm{g} / \mathrm{disc})$, tetracycline (30 $\mu \mathrm{g} / \mathrm{disc})$, neomycin $(30 \mu \mathrm{g} / \mathrm{disc})$, kanamycin (30 $\mu \mathrm{g} / \mathrm{disc})$, chloramphenicol (30 $\mu \mathrm{g} / \mathrm{disc})$, doxycycline (30 $\mu \mathrm{g} / \mathrm{disc})$, ampicillin $(10 \mu \mathrm{g} / \mathrm{disc})$, polymixin $\mathrm{B}$ 
(50 units/disc), penicillin $\mathrm{G}$ (10 units/disc), erythromycin (15 $\mu \mathrm{g} /$ disc), methicillin (5 $\mu \mathrm{g} /$ disc), nalidixic acid (30 $\mu \mathrm{g} / \mathrm{disc})$, gentamycin $(10 \mu \mathrm{g} / \mathrm{disc})$, rifampicin (30 $\mu \mathrm{g} / \mathrm{disc})$, netilin $(30 \mu \mathrm{g} / \mathrm{disc})$, novobiocin $(30 \mu \mathrm{g} / \mathrm{disc})$ and norfloxacin $(30 \mu \mathrm{g} / \mathrm{disc})$. The antibiotic resistance index (ARI) of an organism was expressed as the ratio of the number of resistant antibiotic to the total number of antibiotics tested.

\section{Measurement of growth}

Growth of chromate reducing bacteria in liquid media was measured following the viable count method. The cultures were serially diluted and plated on PYEG agar medium and the number of colony forming units $/ \mathrm{ml}$ was calculated after incubation at $35^{\circ} \mathrm{C}$ for $2-4$ days. Growth of the organisms was also determined by measuring the optical density at $540 \mathrm{~nm}$ using a Systronics Photoelectric Colorimeter (Model 112).

\section{Characterization and identification of bacterial isolates}

The selected bacterial isolates were characterized morphologically and physio-biochemically following standard microbiological methods as described in Gerhardt et al. (1994). The characteristic features of the isolates were compared with those described in Bergey's Manual of Systematic Bacteriology Volume 1 (Holt and Kreig, 1989), Volume 2 (Holt et al., 1989) and Bergey's Manual of Determinative Bacteriology 9th edition (Holt et al., 1994) for determining their taxonomic identity.

\section{Results}

\section{Microbiological characteristics}

Microbial density of the chromite mine overburden samples as revealed by plate count technique was in general low but showed a wide degree of variability, ranging from $0.2-145 \times 10^{4} \mathrm{cfu} / \mathrm{g}$ (Table 1). Fluorescein diacetate hydrolyzing activity of these samples as a measure of the microbial activity also showed a significant variation and maintained a strong positive correlation with total microbial count. The coefficient of correlation (r) between microbial count and FDA hydrolyzing activity of samples from Sukinda Valley and Baula-Nuasahi area were 0.98 and 0.982 respectively.

A total of 130 morphologically distinguishable aerobic heterotrophic bacteria were obtained in pure form. Majority $(58 \%)$ of them were Gram-negative, motile rods forming mostly white to creamish colonies but without any diffusible pigment.

\section{Chromium tolerance of the isolates}

Relative tolerance of these heterotrophic bacterial isolates to hexavalent chromium was evaluated in PYEG agar medium supplemented with $2-8 \mathrm{mM} \mathrm{Cr}^{+6}$. The num-
Table 1 - Microbiological analysis of overburden samples collected from chromite mines of Orissa.

\begin{tabular}{lcccc}
\hline Locality & Site & $\begin{array}{c}\text { Bacterial } \\
\text { count }^{\mathrm{a}} \text {, } \\
\text { cfu/g x 10 }^{4}\end{array}$ & $\begin{array}{c}\text { Microbial activ- } \\
\text { ity }(\mu \mathrm{g} \text { fluores- } \\
\text { cein/g/h) }\end{array}$ & $\begin{array}{c}\text { Number of } \\
\text { bacterial isolates }\end{array}$ \\
\hline $\begin{array}{l}\text { Sukinda valley } \\
\text { Sukinda }\end{array}$ & SUK1 & $0.28 \pm 0.02$ & $1.18 \pm 0.21$ & 11 \\
& SUK2 & $145.0 \pm 0.05$ & $2.36 \pm 0.26$ & 14 \\
& SUK3 & $1.79 \pm 0.06$ & $2.23 \pm 0.26$ & 11 \\
& SUK4 & $130.0 \pm 0.08$ & $2.16 \pm 0.21$ & 12 \\
South & SKP1 & $0.37 \pm 0.04$ & $1.03 \pm 0.20$ & 10 \\
Kaliapani & SKP2 & $6.0 \pm 0.06$ & $1.71 \pm 0.50$ & 13 \\
& SKP3 & $0.20 \pm 0.04$ & $1.07 \pm 0.20$ & 11 \\
Saruabil & SAR1 & $8.60 \pm 0.08$ & $1.79 \pm 0.20$ & 10 \\
& SAR2 & $15.50 \pm 0.07$ & $1.90 \pm 0.26$ & 12 \\
Baula - Nuasahi area & & & 9 \\
Baula & BAU1 & $0.27 \pm 0.80$ & $1.14 \pm 0.20$ & 10 \\
Nuasahi & NUA1 & $1.81 \pm 0.40$ & $1.54 \pm 0.30$ & 7 \\
Bangur & BAN1 & $0.24 \pm 0.29$ & $1.03 \pm 0.21$ & \\
\hline
\end{tabular}

${ }^{a}$ Bacterial count was determined following dilution and plating on peptone yeast extract glucose agar medium. Plates were incubated at $28-32{ }^{\circ} \mathrm{C}$ for 2-4 days.

${ }^{\mathrm{b}}$ Microbial activity was estimated by fluorescein diacetate (FDA) hydrolytic activity following the method of Schnurer and Rosswall (1982).

Results represent mean \pm standard error of triplicate sets.

ber of tolerating isolates decreased gradually with increasing concentration of $\mathrm{Cr}^{+6}$ in the medium. A total of 51 isolates representing about $40 \%$ of the total population tolerated $8 \mathrm{mM}$ of $\mathrm{Cr}^{+6}$. It also revealed that the frequency of occurrence of $\mathrm{Cr}^{+6}$ tolerance among isolates of Baula - Nuasahi area was higher (54\%) than those from Sukinda valley (38\%) (Figure1), even though, the number of bacterial isolates obtained and screened from Baula - Nuasahi was much lower compared to those from Sukinda Valley.

\section{Screening for chromate reduction}

A total of 92 isolates (nearly $70 \%$ of the total population) tolerating $2 \mathrm{mM}$ of $\mathrm{Cr}^{+6}$ was further screened for their chromate reducing potentials in synthetic VB broth and complex KSC medium. Reduction potential of these isolates was more pronounced in $\mathrm{KSC}$ medium than in synthetic VB broth. In all, only three bacterial isolates, SUK 1201, SUK 1205 and SUK 1207 were able to reduce more than 50 and $80 \%$ of initial $2 \mathrm{mM} \mathrm{Cr}^{+6}$ in VB broth and KSC medium respectively, and were selected for in depth studies (Table 2).

\section{Heavy metal tolerance}

The selected isolates showed a wide degree of tolerance to $\mathrm{Cr}^{+6}$ with $\mathrm{MIC}$ values ranging from 8.6 to $17.8 \mathrm{mM}$. 


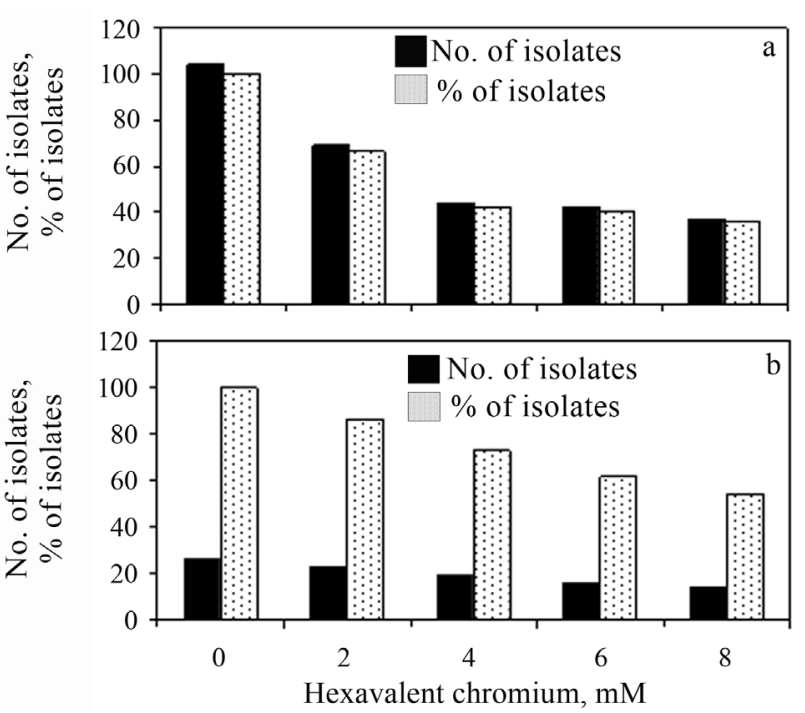

Figure 1 - Tolerance of hexavalent chromium by bacteria isolated from chromite mine overburden of Sukinda valley [a] and Baula - Nuasahi areas [b].

In addition, the isolates were also tolerant to a number of metals like $\mathrm{Ni}^{+2}$ (MIC, 4.9-7.8 mM), $\mathrm{Fe}^{+3}$ (MIC, 4.0 -6.0 mM), $\mathrm{Cu}^{+2}$ (MIC, 2.8 - 5.1 mM) and $\mathrm{Co}^{+2}$ (MIC, 2.24.6 $\mathrm{mM}$ ), but were extremely sensitive to $\mathrm{Hg}^{+2}$ followed by $\mathrm{Cd}^{+2}, \mathrm{Mn}^{+2}$ and $\mathrm{Zn}^{+2}$ (Table 3).

\section{Antibiotic sensitivity}

Antibiotic sensitivity profile of the 3 selected potent $\mathrm{Cr}^{+6}$ reducing bacterial isolates (SUK 1201, SUK 1205 and SUK 1207) as evaluated by disc-diffusion assay against 17 different antibiotics revealed that they are also resistant to a number of antibiotics like penicillin G, ampicillin, novobiocin, norfloxacin, neomycin, methicillin and polymyxin $\mathrm{B}$ but sensitive to streptomycin and chloramphenicol (Figure 2). The antibiotic resistance index (ARI) was highest (0.71) for isolate SUK 1207, while it was 0.65 and 0.53 for isolate SUK 1201 and SUK 1205 respectively.
Table 3 - Minimum inhibitory concentration of heavy metals against selected bacterial isolates from chromite mine overburden.

\begin{tabular}{lccc}
\hline \multirow{4}{*}{ Metals } & \multicolumn{3}{c}{ Minimum inhibitory concentration, $\mathrm{mM}^{\mathrm{a}}$} \\
\cline { 2 - 4 } & \multicolumn{3}{c}{ Bacterial isolate } \\
\cline { 2 - 4 } & SUK 1201 & SUK 1205 & SUK 1207 \\
\hline $\mathrm{Cr}^{+6}$ & 17.8 & 11.8 & 8.6 \\
$\mathrm{Ni}^{+2}$ & 6.4 & 7.8 & 4.9 \\
$\mathrm{Fe}^{+3}$ & 6.0 & 4.0 & 4.0 \\
$\mathrm{Cu}^{+2}$ & 5.1 & 4.8 & 2.8 \\
$\mathrm{Co}^{+2}$ & 4.6 & 4.2 & 2.2 \\
$\mathrm{Mn}^{+2}$ & 3.2 & 3.1 & 1.2 \\
$\mathrm{Zn}^{+2}$ & 4.2 & 2.8 & 2.1 \\
$\mathrm{Cd}^{+2}$ & 2.1 & 2.1 & 3.1 \\
$\mathrm{Hg}^{+2}$ & 0.001 & 0.001 & 0.0015 \\
\hline
\end{tabular}

${ }^{\mathrm{a}} \mathrm{MIC}$ of metals was determined by broth dilution assay (Calomiris et al., 1984) using VB broth.

All metals were used as chloride salts, while $\mathrm{Cr}^{+6}$ was used as chromate.

\section{Characterization of isolates}

All together some 56 characters including morphological, physiological and biochemical properties of the 3 selected potent bacterial isolates were evaluated. Isolate SUK 1207 was Gram-negative motile rod, but both SUK 1201 and SUK 1205 were Gram-positive and showed a unique rod to cocci cycle during growth. The morphological and physio-biochemical characteristics of the isolates were compared with those described in Bergey's Manual of Systematic Bacteriology and Bergey's Manual of Determinative Bacteriology. The isolates SUK 1201 and SUK 1205 were tentatively identified as members of Arthrobacter sp. but differed in terms of colony morphology, motility, production of cellulase, lipase and arginine dihydrolase along with utilization of some carbon sources. On the other hand,

Table 2 - Chromate reduction capacity of chromium resistant bacteria isolated from chromite mine overburden.

\begin{tabular}{|c|c|c|c|c|c|c|c|c|c|}
\hline \multirow[t]{3}{*}{ Locality } & \multirow{3}{*}{$\begin{array}{l}\text { No. of resistant } \\
\text { isolates }^{\mathrm{a}}\end{array}$} & \multicolumn{8}{|c|}{ Percent $\mathrm{Cr}^{+6}$ reduced } \\
\hline & & \multicolumn{2}{|l|}{$0-25$} & \multicolumn{2}{|c|}{$26-50$} & \multicolumn{2}{|c|}{$51-75$} & \multicolumn{2}{|c|}{$76-100$} \\
\hline & & $\mathrm{A}$ & B & A & $\mathrm{B}$ & A & B & A & $\mathrm{B}$ \\
\hline Sukinda valley & 69 & 31 & 10 & 35 & 19 & 3 & 37 & 0 & 3 \\
\hline Baula-Nuasahi area & 23 & 9 & 1 & 14 & 7 & 0 & 15 & 0 & 0 \\
\hline Total & 92 & 40 & 11 & 49 & 26 & 3 & 52 & 0 & 3 \\
\hline$\%$ of organism & 100 & 43.47 & 11.95 & 53.26 & 28.26 & 3.26 & 56.52 & 0 & 3.26 \\
\hline
\end{tabular}

${ }^{\mathrm{a}} \mathrm{Bacterial}$ isolates able to tolerate $2 \mathrm{mM} \mathrm{Cr}^{+6}$ in peptone yeast extract glucose agar medium.

A - Growth and $\mathrm{Cr}^{+6}$ reduction in VB broth, incubation: 10 days at $35^{\circ} \mathrm{C}$ under continuous shaking (120 rpm).

$\mathrm{B}$ - Growth and $\mathrm{Cr}^{+6}$ reduction in $\mathrm{KSC}$ medium, incubation: 10 days at $35^{\circ} \mathrm{C}$ under continuous shaking $(120 \mathrm{rpm})$. 


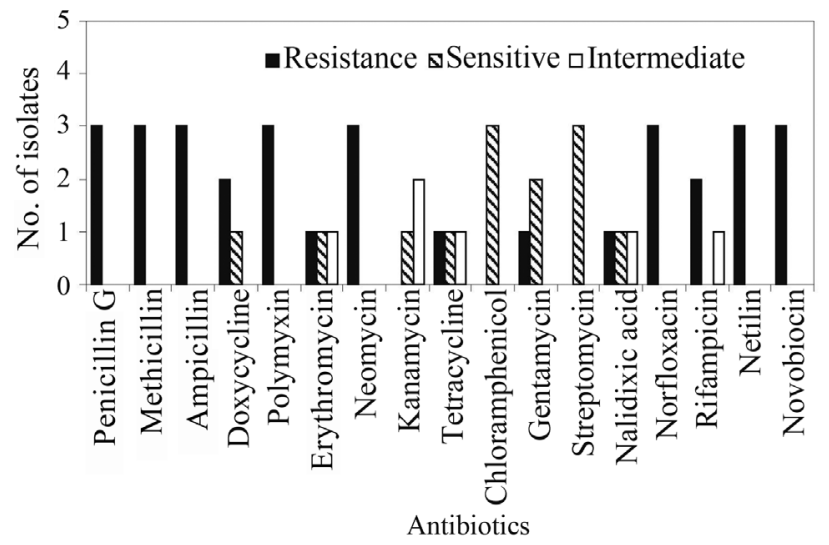

Figure 2 - Antibiotic sensitivity profile of selected bacterial isolates of chromite mine overburden. the isolate SUK 1207 was designated as Pseudomonas sp. (Table 4 and 5).

\section{Time course and chromate reduction}

In chemically defined VB broth, the isolates SUK 1201, SUK 1205 and SUK 1207 reduced nearly 67, 64 and $52 \%$ of initial $2 \mathrm{mM} \mathrm{Cr}^{+6}$ respectively. During the course of the reduction of hexavalent chromium in culture, there was a gradual increase in cell count up to $7^{\text {th }}$ day of incubation, which was $8.42 \pm 0.10,9.06 \pm 0.12$ and $8.8 \pm 0.10 \log$ no. of cells/mL for isolates SUK 1201, SUK 1205 and SUK 1207 respectively. This was accompanied with a gradual change in the colour of the medium which turned yellow to pale green with formation of visible green precipitates. Maximum precipitation was obtained with isolate SUK 1201

Table 4 - Morphological, physiological and biochemical characteristics of some selected bacterial isolates from chromite mine overburden.

\begin{tabular}{|c|c|c|c|}
\hline \multirow[t]{3}{*}{ Characters } & \multicolumn{3}{|c|}{ Response } \\
\hline & \multicolumn{3}{|c|}{ Bacterial isolate } \\
\hline & SUK 1201 & SUK 1205 & SUK 1207 \\
\hline \multicolumn{4}{|l|}{ Morphological } \\
\hline Colony & Round convex pale yellow & Round convex white & Round convex white \\
\hline Gram nature & $+\mathrm{ve}$ & $+\mathrm{ve}$ & -ve \\
\hline Shape & Rod - coccus cycle & Rod - coccus cycle & Rods \\
\hline Arrangement & Single & Chain & Single \\
\hline Endospore & - & - & - \\
\hline Motility & - & + & + \\
\hline \multicolumn{4}{|l|}{ Physiological } \\
\hline Diffusible pigment & - & - & - \\
\hline Range of $\mathrm{pH}$ for growth & $5.0-9.0$ & $5.0-9.0$ & $4.0-8.0$ \\
\hline Growth in Kings B & + & + & + \\
\hline Growth in Mac Conkey agar & - & - & - \\
\hline $\mathrm{NaCl}$ tolerance $(\%)$ & 2.5 & 8.5 & 1.0 \\
\hline Siderophore production & + & + & + \\
\hline \multicolumn{4}{|l|}{ Biochemical } \\
\hline Citrate utilization & - & \pm & - \\
\hline Lysine decarboxylase & - & - & - \\
\hline Ornithine decarboxylase & - & - & - \\
\hline Urease production & - & - & - \\
\hline Nitrate reduction & - & - & - \\
\hline $\mathrm{H}_{2} \mathrm{~S}$ production & - & - & - \\
\hline Cellulase production & + & - & + \\
\hline Lipase production & - & + & - \\
\hline Gelatinase production & - & - & - \\
\hline Methyl red test & - & - & - \\
\hline Catalase production & + & + & + \\
\hline Voges Proskaur test & - & - & - \\
\hline Amylase production & - & - & + \\
\hline Indole production & - & - & - \\
\hline Oxidase production & + & + & + \\
\hline Cytochrome oxidase & - & - & + \\
\hline Arginine dihydrolase & - & + & + \\
\hline
\end{tabular}




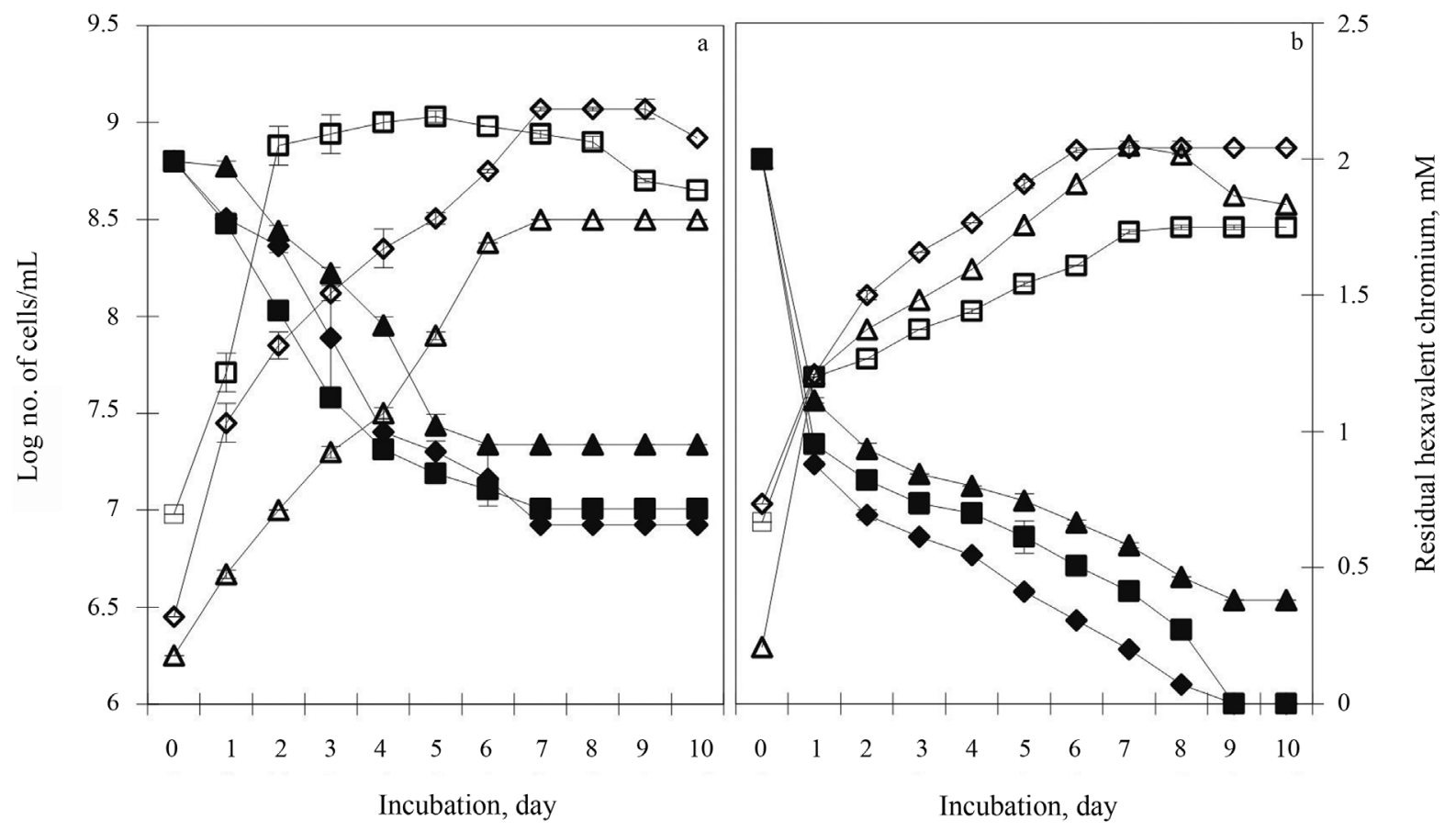

Figure 3 - Time course of growth and hexavalent chromium reduction by selected bacterial isolates in VB broth [a] and KSC medium [b] (Growth: - $\square-$ SUK 1201, - $\Delta$ - SUK 1205, - - - SUK 1207; $\mathrm{Cr}^{+6}$ reduction: - $\square$ - SUK 1201, - $\mathbf{-}$ - SUK 1205, - - - SUK 1207).

where the $\mathrm{Cr}^{+6}$ level in the medium declined to $0.66 \mathrm{mM}$ indicating $67 \%$ reduction (Figure $3 \mathrm{a}$ ). In complex KSC medium containing $1 \%$ glucose, the chromate reduction was much more pronounced. Complete reduction of $2 \mathrm{mM} \mathrm{Cr}^{+6}$ in the medium was achieved with bacterial isolates SUK 1201 and SUK 1205, while SUK 1207 showed only 81\% reduction. As in VB broth, there was also a gradual increase in cell number up to the $7^{\text {th }}$ day of incubation (Figure $3 \mathrm{~b}$ ).

\section{Growth associated reduction in mine seepage}

Considering the efficient reduction potential in $\mathrm{KSC}$ medium and VB broth, bacterial isolates SUK 1201 and SUK 1205, were further evaluated for reduction of $\mathrm{Cr}^{+6}$ $(60 \mu \mathrm{M})$ contained in natural mine seepage under 3 different experimental conditions. These include: i) direct use of mine seepage, ii) mine seepage supplemented with $0.1 \%$ glucose and iii) mine seepage supplemented with VB broth. Results show that isolates SUK 1201 and SUK 1205 could reduce 34 and $41 \%$ of $60 \mu \mathrm{M}$ of $\mathrm{Cr}^{+6}$ in mine seepage water respectively. However, their reducing ability was increased to 58 and $68 \%$ when mine seepage was supplemented with $0.1 \%$ glucose (Figure $4 \mathrm{a}, \mathrm{b}$ ). Interestingly, hexavalent chromium was completely reduced by both the isolates when mine seepage was supplemented with $2 \%$ VB concentrate.

\section{Discussion}

The present microbiological analysis clearly demonstrates that the chromite mine overburden samples which are usually rich in mineral contents but poor in organic substances are not inferior in microbial density as well as diversity compared to other chromium contaminated soils (Table 1). Existence of such diverse type of microbiota in chromite mine overburden has previously been demonstrated (Acharya et al., 1998). It was also evident that the microbial activity of the samples was positively correlated with total microbial count and the calculated $r$ value was highly significant at $\mathrm{p}=0.001$. The microbial population was dominated by Gram-negative (58\%) organisms contrary to the high frequency of Gram-positive bacteria in metal polluted areas (Viti et al., 2003; Mishra et al., 2010).

The bacterial isolates derived from the chromite mining environment showed a high level of tolerance to chromium, about 35 and $54 \%$ of isolates from Sukinda Valley and Baula - Nuasahi area respectively tolerated upto $8 \mathrm{mM}$ chromium (Figure 1). Such an adaptation and tolerance to chromium was evident in indigenous microbiota of chromite mine soils (Dhal et al., 2010) as well as in anthropogenic (Basu et al., 1997; Viti et al., 2003) and geogenous (Pal and Paul, 2004) environments. In addition, isolates like Aeromonas and Pantoea sp. (Alam and Ahmad, 2011) were found to tolerate upto $4.7 \mathrm{mM}$ of $\mathrm{Cr}^{+6}$, whereas Thermus scotocductus isolated from mine ground water (Opperman and Heerden, 2007) tolerated $0.3 \mathrm{mM} \mathrm{Cr}^{+6}$.

The microbial cells in order to combat the metal stressed conditions have developed several resistance mechanisms such as exclusion of metals by permeability barrier, active transport of metal, intracellular sequestration of metal by binding of proteins, extracellular sequestration, 
Table 5 - Utilization and fermentation of different carbon sources by some selected bacterial isolates from chromite mine overburden.

\begin{tabular}{|c|c|c|c|}
\hline \multirow[t]{3}{*}{ Characters } & \multicolumn{3}{|c|}{ Response } \\
\hline & \multicolumn{3}{|c|}{ Bacterial isolate } \\
\hline & SUK 1201 & SUK 1205 & SKPD 1207 \\
\hline \multicolumn{4}{|c|}{ Carbon source } \\
\hline \multicolumn{4}{|c|}{ Utilization of } \\
\hline Glucose & + & + & + \\
\hline Sucrose & + & + & + \\
\hline Fructose & + & + & - \\
\hline Maltose & + & + & + \\
\hline Lactose & + & + & - \\
\hline Galactose & + & + & - \\
\hline Trehalose & + & + & - \\
\hline Rhamnose & + & + & - \\
\hline Raffinose & + & - & - \\
\hline Mannose & - & + & - \\
\hline Arabinose & - & + & - \\
\hline Cellobiose & + & - & - \\
\hline Xylose & + & + & - \\
\hline Salicin & + & - & - \\
\hline Adonitol & - & - & - \\
\hline Mannitol & + & + & - \\
\hline Glycerol & + & + & + \\
\hline
\end{tabular}

Fermentation of

Glucose

Sucrose

Fructose

Lactose

Galactose

Rhamnose

Arabinose

Adonitol

Mannitol

Sorbitol

Generic identity Arthrobacter sp. Arthrobacter sp. Pseudomonas sp.

enzymatic detoxification of metal ions to less toxic forms and reduction of metal sensitivity of cellular targets (Nies, 1999). Chromium tolerant microorganisms have been reported to develop strategies to detoxify the elevated levels of toxic chromate and dichromate. This is accomplished by transforming $\mathrm{Cr}^{+6}$ to less toxic $\mathrm{Cr}^{+3}$ via possible reduction systems or through intracellular or extracellular sequestration of metal ions making them unavailable to the ecosystem (Williams and Silver, 1984; Pattanapipitpaisal et al., 2002; Camargo et al., 2003).

It was evident that the chromate reduction efficiency of bacterial isolates derived from two distantly separated localities was significantly different and not correlated with their limit of chromium tolerance (Table 2). This supports the earlier observations that chromate reduction ability of bacterial isolates is not correlated with chromium resistance (Pattanapipitpaisal et al., 2001).

Like majority of the metal resistant bacteria, chromium resistant and reducing bacteria isolated from chromite overburden also exhibited the feature of multi-metal tolerance (Table 3) as well as resistance to a number of antibiotics (Figure 2). Such tolerance of the microbial communities to $\mathrm{Ni}^{+2}, \mathrm{Fe}^{+3}, \mathrm{Cu}^{+2}$ and $\mathrm{Co}^{+2}$ might be due to the selection of the pre-existing systems for metal tolerance or induction of the expression of selective gene or gene clusters. Similarly, co-existence of metal and antibiotic resistance in $\mathrm{Cr}^{+6}$ reducing bacteria has been reported by several others (Ganguli and Tripathi, 2002; Viti et al., 2003; Pal et al., 2005; Jain et al., 2009). It may be presumed that antibiotic resistance in these bacteria might have been induced as a result of selective pressure created by the metal pollution and horizontal transfer of associated antibiotic resistance genes.

The selected bacterial isolates were characterized phenotypically and two of them, SUK 1201 and SUK 1205 were found to belong to Arthrobacter sp., while SUK 1207 was placed under Pseudomonas sp. (Tables 4 and 5). Actinomycetes like Arthrobacter capable of reducing chromate is not uncommon in chromium polluted waste water treatment plants (Molokwane et al., 2008). Likewise, occurrence of pseudomonads was evident in metal polluted environments (Luli et al., 1983; Camargo et al., 2003) and chromite mine effluents (Lebedeva and Lyalikova, 1979; Dey and Paul, 2010).

Quantitative evaluation of $\mathrm{Cr}^{+6}$ reduction by the selected isolates during growth under shake-flask condition using chemically defined (Figure $3 \mathrm{a}$ ) and complex organic media (Figure $3 \mathrm{~b}$ ) clearly established the superiority of isolates SUK 1201 and SUK 1205 over that of SUK 1207, which was not inferior. Interestingly, there was clear demonstration of formation of white to green precipitates of insoluble chromium species simultaneously with the transformation of $\mathrm{Cr}^{+6}$ in the medium.

Moreover, the most efficient Arthrobacter strains, SUK 1201 and 1205 completely reduced the hexavalent chromium of the mine seepage when supplemented with V. B. concentrate (Figure $4 \mathrm{a}, \mathrm{b}$ ). Similar approaches made by Molokwane et al. (2008) with a consortium of indigenous microbiota isolated from Brits, South Africa showed 94\% removal of $\mathrm{Cr}^{+6}$ in $24 \mathrm{~h}$ of incubation. The present observations, therefore, clearly demonstrate that the Arthrobacter strains indigenous to chromite overburden could find practical applications in the bioremediation of chromium pollutants in mining environments through the development of suitable microbial technology. 

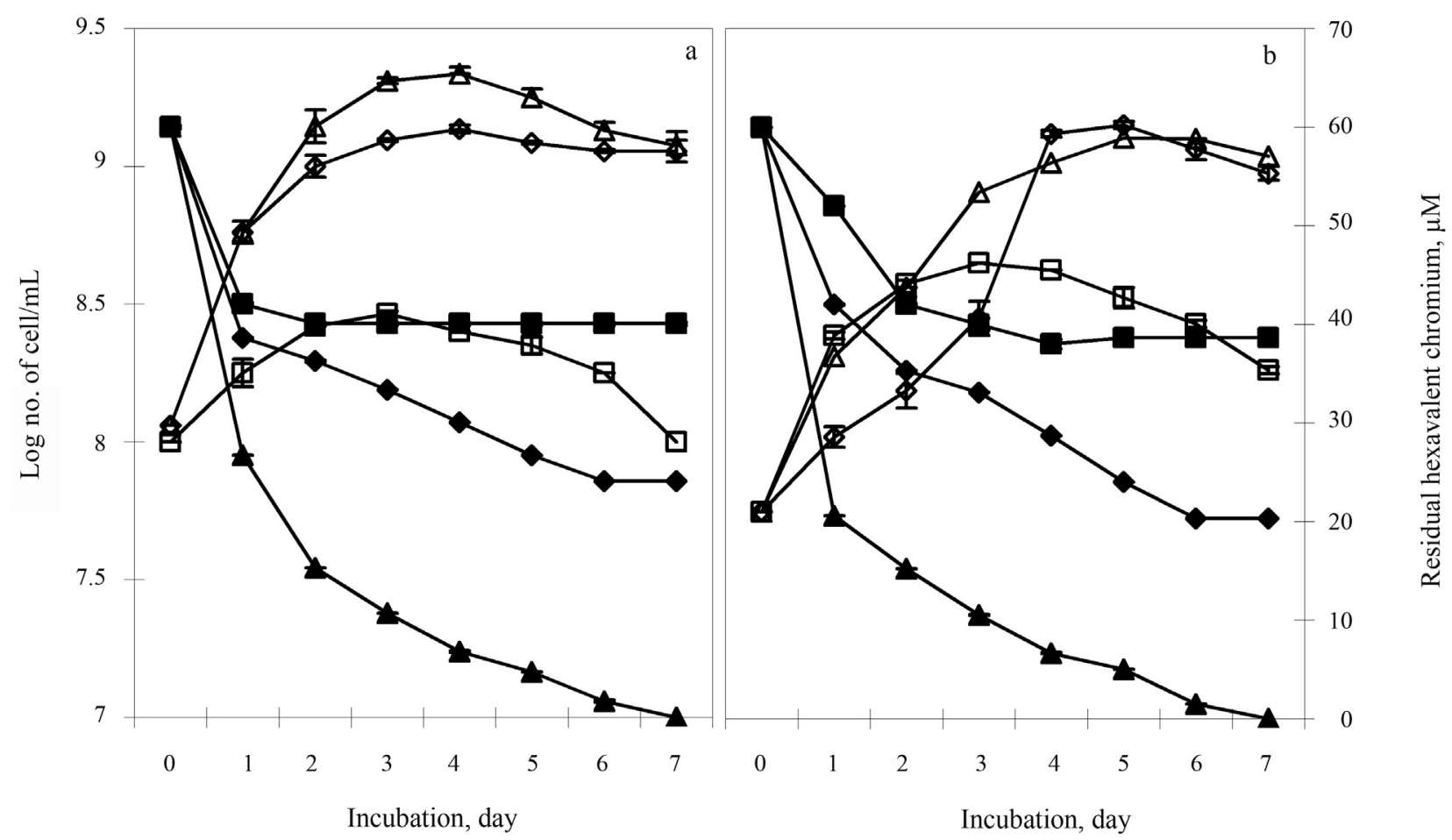

Figure 4 - Growth and reduction of hexavalent chromium in mine seepage water by bacterial isolates SUK 1201 [a] and SUK 1205 [b] under different experimental conditions (Growth: $-\square$ - mine seepage, $-\Delta$ - mine seepage + glucose, $-\diamond$ - mine seepage $+\mathrm{VB}$ broth; $\mathrm{Cr}^{+6}$ reduction : - - - mine seepage, $-\mathbf{\Delta}$ - mine seepage + glucose, $-\diamond$ - mine seepage + VB broth).

\section{Acknowledgments}

The authors duly acknowledge the financial support from the Department of Biotechnology, Ministry of Science and Technology, Government of India vide Sanction number BT/PR/5766/NDB/51/061/2005. The authors are grateful to Tata Iron and Steel Company (TISCO) and Orissa Mining Corporation (OMC) for providing permission and logistic support in sample collection.

\section{References}

Acharya C, Kar RN, Sukla LB (1998) Leaching of chromite overburden with various native bacterial strains. World J Microbiol Biotechnol 14:769-771.

Alam MZ, Ahmad S (2011) Toxic chromate reduction by resistant and sensitive bacteria isolated from tannery effluent contaminated soil. Ann Microbiol DOI 10.1007/s13213-011-0235-4.

Bagchi D, Stohs SJ, Bernard WO, Bagchi M, Preus HG (2002) Cytotoxicity and oxidative mechanism of different forms of chromium. Toxicol 180:5-22.

Basu M, Bhattacharya S, Paul AK (1997) Isolation and characterization of chromium-resistant bacteria from tannery effluents. Bull Environ Cont Toxicol 58:535-542.

Calomiris JJ, Armstrong TL, Seidler RJ (1984) Association of metal-tolerance with multiple antibiotic resistance of bacteria isolated from drinking water. Appl Environ Microbiol 47:1238-1242.
Camargo FAO, Okeke BC, Bento FM, Frankenberger WT (2003) In vitro reduction of hexavalent chromium by a cell-free extract of Bacillus sp. ES 29 stimulated by $\mathrm{Cu}^{2+}$. Appl Microbiol Biotechnol 62:569-573.

Cervantes C, Ohtake H (1988) Plasmid-determined resistance to chromate in Pseudomonas aeruginosa. FEMS Microbiol Lett 56:173-176.

Dey S, Paul AK (2010) Occurrence and evaluation of chromium reducing bacteria in seepage water from chromite mine quarries of Orissa, India. J Water Resource Prot 2:380-388.

Dhal B, Thatoi H, Das N, Pandey BD (2010) Reduction of hexavalent chromium by Bacillus sp. isolated from chromite mine soils and characterization of reduced product. J Chem Technol Biotechnol 85:1471-1479.

Difco Laboratories (1984) DIFCO Manual: Dehydrated Culture Media and Reagents for Microbiology. $10^{\text {th }}$ edition. DIFCO Laboratories Inc., Detroit, 1155 pp.

Ganguli A, Tripathi AK (2002) Bioremediation of toxic chromium from electroplating effluents by chromate-reducing Pseudomonas aeruginosa A2Chr in two bioreactors. Appl Microbiol Biotechnol 58:416-420.

Gerhardt P, Murray RGE, Wood WA, Krieg NR (1994) Methods for General and Molecular Bacteriology. American Society for Microbiology, Washington DC, 791 pp.

Godgul G, Sahu KC (1995) Chromium contamination from chromium mine. Environ Geol 25:251-257.

Holt JG, Krieg NR (1989) Bergey's Manual of Systematic Bacteriology, Vol 1. Williams and Wilkins, Baltimore, 964 pp. 
Holt JG, Sneath PHA, Mair NS, Sharpe ME (1989) Bergey's Manual of Systematic Bacteriology, Vol 2. Williams and Wilkins, Baltimore.

Holt JG, Kreig NR, Sneath PH, Staley JT, Williams ST (1994) Bergey's Manual of Determinative Bacteriology. $9^{\text {th }}$ edition. Williams and Wilkins, Baltimore.

Jain PK, Ramachandran S, Shukla V, Bhakuni D, Verma SK (2009) Characterization of metal and antibiotic resistance in a bacterial population isolated from copper mining industry. Int J Integrative Biol 6:57-61.

Komori K, Toda K, Ohtake H (1990) Effects of oxygen stress on chromate reduction in Enterobacter cloacae HO1. J Ferment Bioeng 69:67-69.

Lebedeva EV, Lyalikova NN (1979) Reduction of crocoite by Pseudomonas chromatophila sp. nov. Mickobiologia 48:517-522.

Luli GW, Joseph WL, William RS, Robert MP (1983) Hexavalent chromium resistant bacteria isolated from river sediments. Appl Environ Microbiol 46:846-854.

Megharaj M, Avudainayagam S, Naidu R (2003) Toxicity of hexavalent chromium and its reduction by bacteria isolated from soil contaminated with tannery waste. Curr Microbiol 47:51-54.

Mishra V, Samantaray DP, Dash SK, Mishra BB, Swain RK (2010) Study on hexavalent chromium reduction by chromium resistant bacterial isolates of Sukinda mining area. Our Nature 8:63-71.

Molokwane PE, Meli CK, Chirwa EMN (2008) Chromium (VI) reduction in activated sludge bacteria exposed to high chromium loading: Brits culture (South Africa). Water Res 42:4538-4548.

Nies DH (1999) Microbial heavy metal resistance. Appl Microbiol Biotechnol 51:730-750.

Opperman DJ, van Heerden E (2007) Aerobic Cr(VI) reduction by Thermus scotoductus strain SA-01. J Appl Microbiol 103:1907-1913.

Pal A, Paul AK (2004) Aerobic chromate reduction by chromium-resistant bacteria isolated from serpentine soil. Microbiol Res 159:347-354.

Pal A, Dutta S, Mukherjee PK, Paul AK (2005) Occurrence of heavy metal-resistance in microflora from serpentine soil of Andaman. J Basic Microbiol 45:207-218.

Park CH, Keyhan B, Wielinga B, Fendorf S, Matin A (2000) Purification to homogeneity and characterization of a novel Pseudomonas putida chromate reductase. Appl Environ Microbiol 66:1788-1795.
Pattanapipitpaisal P, Brown NL, Macaskie LE (2001) Chromate reduction and $16 \mathrm{~S}$ rRNA identification of bacteria isolated from a $\mathrm{Cr}$ (VI) contaminated site. Appl Microbiol Biotechnol 57:257-261.

Pattanapipitpaisal P, Mabbett AN, Finlay JA, Beswick AJ, Paterson-Beedle M, Essa A, Wright J, Tolley MR, Badar U, Ahmed N, Hobman JL, Brown NL, Macaskie LE (2002) Reduction of $\mathrm{Cr}(\mathrm{VI})$ and bioaccumulation of chromium by Gram positive and Gram negative microorganisms not previously exposed to Cr stress. Environ Technol 23:731-745.

Samantaroy S, Rout GS, Das P (1999) Studies on uptake of heavy metals by various plant species on chromite mine spoils in subtropical regions of India. Environ Monit Asses 55:389-399.

Schnurer J, Rosswall T (1982) Fluorescein diacetate hydrolysis as a measure of total microbial activity in soil and litter. Appl Environ Microbiol 43:1256-1261.

Thaker U, Madamwar D (2005) Reduction of toxic chromium and partial localization of chromium reductase activity in bacterial isolate DM1. World J Microbiol Biotechnol 21:891-899.

Thacker U, Parikh R, Shouche Y, Madamwar D (2006) Hexavalent chromium reduction by Providencia sp. Process Biochem 41:1332-1337.

Tiwary RK, Dhakate R, Ananda RV, Singh VS (2005) Assesment and prediction of contaminant migration in ground water from chromite waste dump. Environ Geol 48:420-429.

Viti P, Pace A, Giovannetti L (2003) Characterisation of chromium-resistant bacteria isolated from chromium-contaminated soil by tannery activity. Curr Microbiol 46:1-5.

Wang PC, Mori T, Komori K, Sasatsu M, Toda K, Ohtake H (1989) Isolation and characterization of an Enterobacter cloacae strain that reduces hexavalent chromium under anaerobic conditions. Appl Environ Microbiol 55:1665-1669.

Wang YT, Xiao C (1995) Factors affecting hexavalent chromium reduction in pure cultures of bacteria. Water Res 29:2467-2474.

Wani R, Kodam KM, Gawai KR, Dhakephalkar PK (2007) Chromate reduction by Burkholderia cepacia MCMB-821 isolated from the pristine habitat of alkaline crater lake. Appl Microbiol Biotechnol 75:627-632.

Willams WJ, Silver S (1984) Bacterial detoxification and resistance to heavy metals. Enzyme Microbiol Biotechnol 6:530-537.

All the content of the journal, except where otherwise noted, is licensed under a Creative Commons License CC BY-NC. 